\title{
超電導発電機用大型 $\mathrm{Ni}$ 基合金回転子の開発
}

\author{
松本 修) 村井康 生兌 \\ 津田陽一苂 鈴木信久2)
}

\section{1. は じめに}

年々増大する電力需要に対して省エネルギーおよび環境保 全への配慮が注目されている中, 通産省工業技術院の二ュー サンシャイン計画の一環として超電導発電機の開発を新エネ ルギー産業技術総合開発機構が推進している. 超電導発電機 は界磁巻線に金属超電導線を用い，液体へリウム中 $(4 \mathrm{~K})$ で 冷却し, 超電導状態(電気抵抗が 0 の状態)で発電すること により, 従来の発電機に比べ，下記の効果が期待できる.

(1) 発電効率が $1 \%$ 増加する.

（2）発電機が小型軽量化(従来の $1 / 2$ の大きさ)する.

（3）系統安定度が向上し, 送電電力が $1.2 \sim 1.5$ 倍になる. これらの省エネルギー効果により, 実用化されれば, $\mathrm{CO}_{2}$ 排出量が大幅に削減でき地球環境保全問題にも大きく貢献で きる. 上記の効果に加えて, 励磁の速応制御を可能(超速応 型)にすることにより系統安定度を大幅に増大させることが でき，多額の送電線設備費の節約が可能になる．この超速応 型超電導発電機の回転子構造材料には常温から極低温 $(4 \mathrm{~K})$ の温度域まで高強度，高電気抵抗率，高勒性，拈よび良好な 溶接性を有する非磁性合金が必要となる，また，大型鍛造品 が必要となるため，内部品質の優れた鋳塊扎よび均質な大型 鍛造品の製造技術を確立することが重要である．著者らは， 高強度の $\mathrm{Ni}$ 基耐熱超合金をべースに改良を加え，常温から 極低温まで強度，電気抵抗率，勒性が高く，溶接性の良好な $\mathrm{Ni}$ 基超合金の母材および溶接材料を開発した。また， Ni 基

* 株式会社神戸製鋼所

1)鋳鍛鋼工場担当課長 2)材料研究所主任研究員

** 株式会社東芝

1) 重電技術研究所主務 2) 京浜事業所機器装置部主務

Development of Ni-base Superalloy Rotor Forging for Superconducting Generators; Osamu Matsumoto*, Yasuo Murai*, Yoichi Tsuda**, Nobuhisa Suzuki**(*Kobe Steel Ltd., **Toshiba Corporation) 1998年 1 月26日受理
超合金としては世界最大級の 14 トンの大型鋳塊ならびにそ の鍛造品の製造技術を開発し，発電容量としては世界最大の $70 \mathrm{MW}$ 超速応型超電導発電機用の回転子の製造に成功し た.

\section{2. 母材および溶接材料用合金の開発}

（1）母材合金の開発

超電導発電機の回転子鍛造品の母材の候補材としては, 従 来からガスタービン部品などに使用されている Ni 基の耐熱 超合金である706や718合金が挙げられる。これらの合金は 高強度であるが，溶接熱影響部(HAZ)にミクロ割れを生じ る問題がある。これは粒界の $\mathrm{NbC}$ の溶融が原因とされてい る(1). また, 鋳塊を大型化すると, $\mathrm{Nb}, \mathrm{Ti}$ 等のマク口偏析 によりフレックルと呼ばれる炭化物, Laves 相を主とした析 出物の密集帯を生じ, 勒性を著しく劣化させる問題がある ${ }^{(2)}$. しかし, $\mathrm{Nb}$ や Ti は $\gamma^{\prime} や \gamma^{\prime \prime}$ 相による析出強化に必要な成分 である，そこで上記従来合金を基本成分とした $20 \mathrm{~kg}$ の小型 溶解材を用い, 強度, 勒性, 溶接性に拝よぼす $\mathrm{Nb}$ と $\mathrm{Ti}$ の 影響を調査した. その結果, 図 1 および図 2 に示すよらに要 求強度，勒性を満足し，HAZ 割れを抑制できる合金として， $\mathrm{Nb}, \mathrm{Ti}$ を $3.5 \leqq(\mathrm{Nb}+\mathrm{Ti}) \mathrm{wt} \% \leqq 4.5$ の範囲に制御し, C, Si, $\mathrm{B}$ を低下した $40 \mathrm{Ni}-15 \mathrm{Cr}-2.3 \mathrm{Nb}-1.5 \mathrm{Ti}-\mathrm{Fe}$ 合金を新しく開発 した(3).

\section{（2）溶接材料用合金の開発}

溶接材料は従来718合金の TIG 溶接材料(ワイヤ)が市販 されているが，30 mm を超えるような厚肉溶接部には溶接 金属に割れが発生し，また勒性が低く要求性能を満足しない 問題がある.そこで母材と同様に小型溶解材から種々の TIG 溶接ワイヤを製造し, $30 \mathrm{~mm}$ 厚みの板の継手溶接を行 い, 溶接施工条件を变化させて溶接部の割れ感受性および機 械的性質を調查した。 その結果, 割れ発生の原因となる炭化 物や Laves 相などの有害相の析出物を抑制し，良好な勒性 
を有する溶接材料用の合金として Nb, Si，Bを低減した $51 \mathrm{Ni}-15 \mathrm{Cr}-3 \mathrm{Mo}-2.7 \mathrm{Nb}-1.7 \mathrm{Ti}-\mathrm{Fe}$ 合金(3)を開発した. 図3に 示したように開発合金の溶接金属は従来合金にくらべて, 優 れた勒性が得られている.

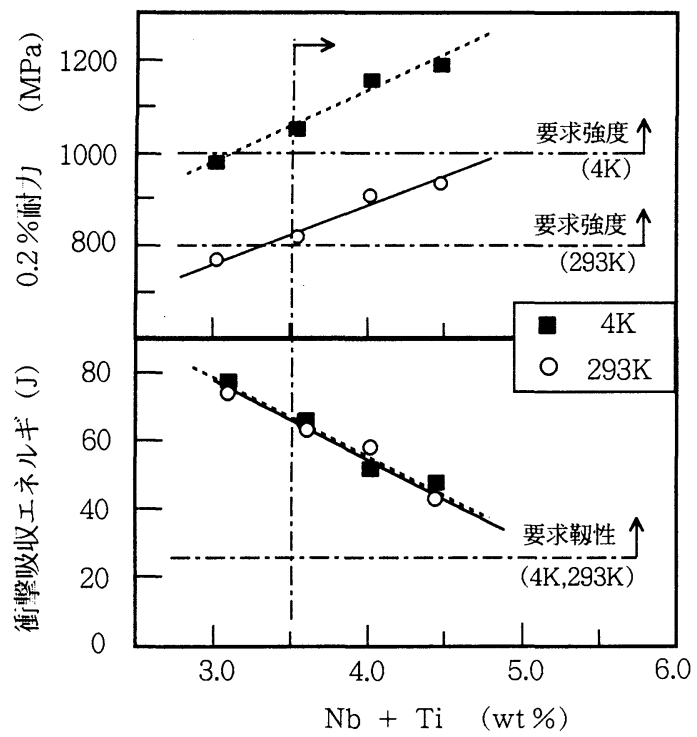

図 1 室温および $4 \mathrm{~K}$ での $0.2 \%$ 耐力と $(\mathrm{Nb}+\mathrm{Ti})$ 量の 関係.

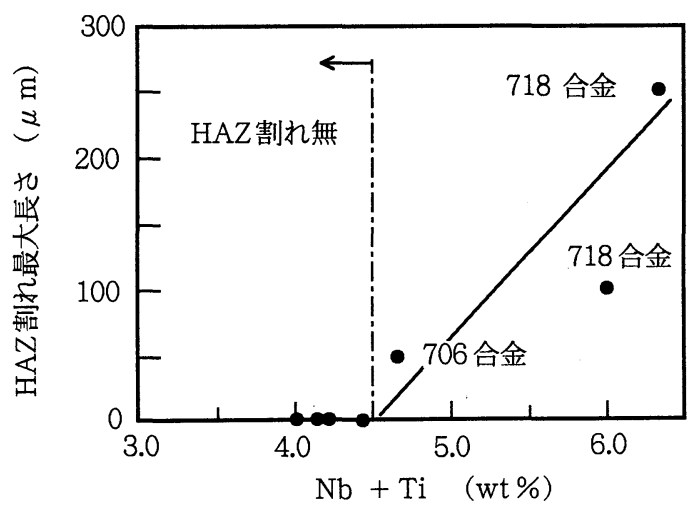

図 2 溶接熱影響部 $(\mathrm{HAZ})$ 割れ最大長さと $(\mathrm{Nb}+\mathrm{Ti})$ 量 の関係.

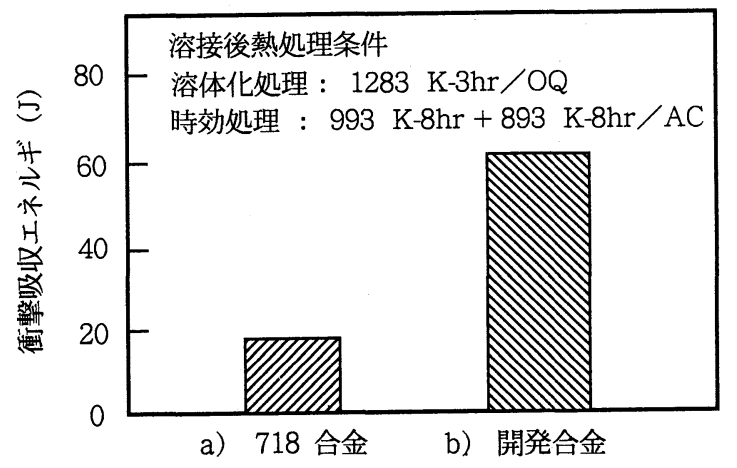

図 3 開発材と従来材の溶接金属部の勒性比較.

\section{（3）大型化技術の開発}

$\mathrm{Ni}$ 基超合金は析出強化元素や固溶強化元素を多く含んで いるため, 通常, ESR(エレクトロスラグ再溶解)あるいは $\mathrm{VAR}$ (真空アーク再溶解)など 2 次溶解によって鋳塊を製造 し, 凝固組織の均質化拉よび微細化を図っている. しかし， 数トンを超える大型鍛造品の製造には限界があった。それは 前述したように，鋳塊を大型化するとフレックルを生じ，勒 性などの機械的性質を著しく劣化させる問題があるためであ る. 大型化技術の開発は, 2 トン鋳塊 ${ }^{(4)}$, 7 トン鋳塊, 11 ト ン鋳塊 ${ }^{(5)}$ と徐々に大型化の試作を進めながら, 大型 ESR 溶 解条件, 大型鍛造品内部全体に渡る均質な性能を得るための 結晶粒微細化鍛造方法の検証を行い性能評価を行った. その 結果, ESR 溶解速度を低速かつ安定的に操業することによ って，内部品質の優れた世界最大級の鋳塊が製造でき，ま た，鍛造温度と歪量を最適にコントロールすることにより， 均質かつ微細な結晶粒組織を有した大型鍛造品の製造を可能 にした.

\section{3. $70 \mathrm{MW}$ 超電導発電機回転子の製造}

（1）製 造

上記の検討結果に基づき, $70 \mathrm{MW}$ 超電導発電機の回転子 の製造を行った. 超電導発電機回転子は巻線取付軸部とトル クチューブとから成り，これらを溶接して製造する．それぞ れの製造工程を図 4 に示す. 1 次溶解は電弧炉および真空取 鍋精鍊炉により行い, ESR 電極とした. ついで, ESRを行 い, 直径 $810 \mathrm{~mm}$, 質量 14 トンの大型鋳塊とした。本 ESR 鋼塊は最大 13000 トン容量のプレスを用いて圧縮, 鍛伸を繰 り返し行い，最終的に円柱軸形状に鍛造した．回転子両端に 取り付けられるトルクチューブも，同一成分の 2 トンの ESR 鋳塊からリング鍛造により製造した．これら鍛造品は 溶接前溶体化処理を行い, 開先加工を行った後, 開発した溶 接材料(ワイヤ)を用いて TIG 溶接を行った. 再度, 溶体化 処理後, 界磁巻線を取り付けるスロット(溝)等の粗加工後, 時効処理を行い強度を付与した. 性能評価は回転子の種々の 部位から試験片を採取し, 材料試験, 物理試験を行った。

回転子の概略形状と試験片採取位置を図 5 に示す．溶接部 の評価は取付軸およびトルクチューブ余長部から切断したり ング材を用いて, 本体と同一条件で溶接, 熱処理したテスト リング継手を製作し，これから試験片を採取し，各種材料試 験を行った。

\section{（2）評 価}

回転子各部位の主要化学成分を表 1 に示す．巻線取付軸は $\mathrm{Ni}$ 基超合金としては世界最大級の鋳塊であるが，目標通り の成分が得られている. また，各部位の機械的性質は表 2 に 示すよらに要求性能を十分満足するものであり，極低温に拉 


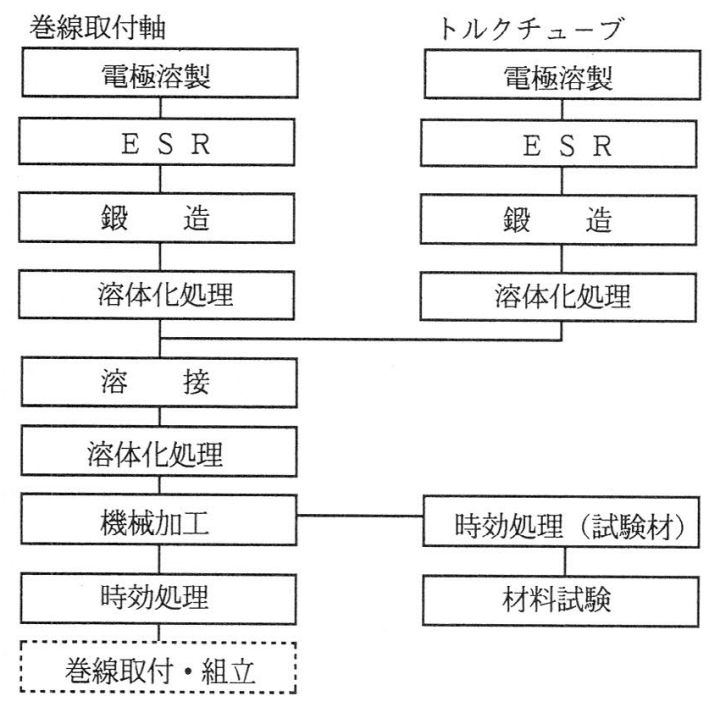

図 $470 \mathrm{MW}$ 超電導発電機回転子主要製造工程.

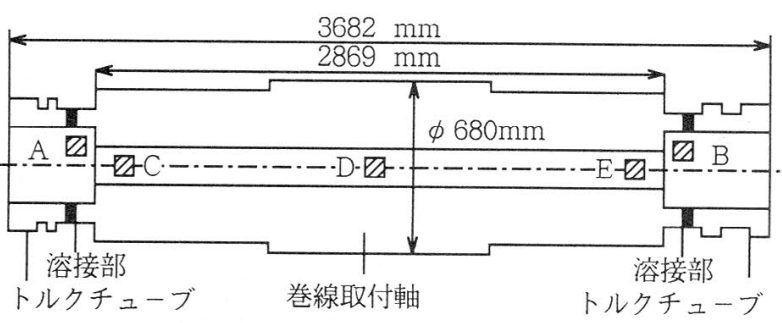

図 5 回転子概略形状と試験片採取位置.

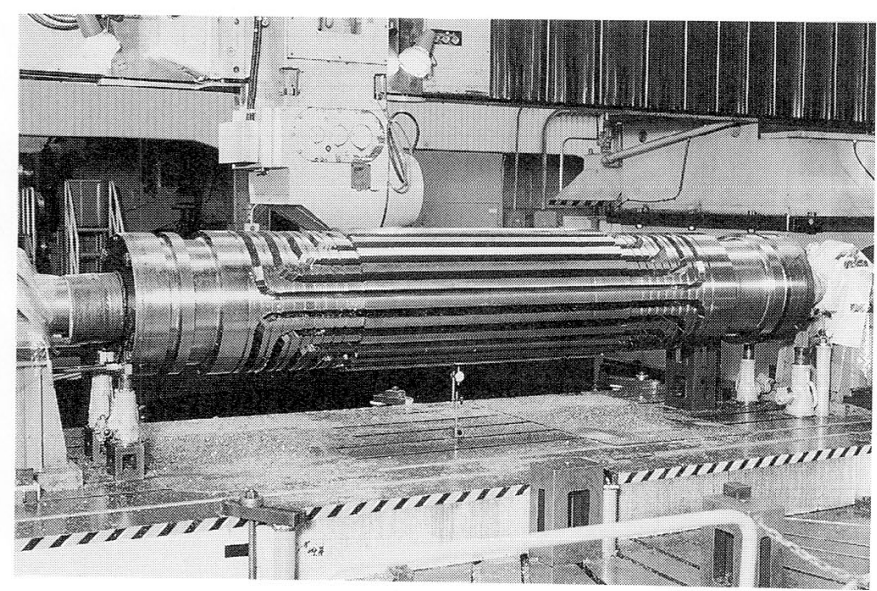

図 $670 \mathrm{MW}$ 超電導発電機回転子素材外観写真.

いても良好な結果が得られた。図 6 亿は本 $70 \mathrm{MW}$ 超電導発 電機回転子の界磁巻線 (超電導線)取付前の外観写真を示 寸.

現在，この $70 \mathrm{MW}$ 機は回転子の製作はほぼ完了し，98年 度半ばから関西電力(蚮大阪発電所内に設けられた試験センタ 一にて発電運転予定であり, 実用化に向けて着実な進歩を遂 げている。
表 1 回転子各部位の主要化学成分 (wt \%).

\begin{tabular}{c|c|c|c|c|c|c|c|c|c|c}
\hline \hline \multicolumn{2}{c|}{ 部 位 } & $\mathrm{C}$ & $\mathrm{Si}$ & $\mathrm{Ni}$ & $\mathrm{Cr}$ & $\mathrm{Mo}$ & $\mathrm{Al}$ & $\mathrm{Ti}$ & $\mathrm{Nb}$ & $\mathrm{Fe}$ \\
\hline $\begin{array}{c}\text { 巻 線 } \\
\text { 軸由 }\end{array}$ & $\mathrm{A}$ & 0.02 & 0.08 & 40.7 & 14.8 & - & 0.14 & 1.6 & 2.4 & $\mathrm{Bal}$. \\
\cline { 2 - 11 } & $\mathrm{B}$ & 0.02 & 0.12 & 40.6 & 14.8 & - & 0.15 & 1.5 & 2.4 & $\mathrm{Bal}$. \\
\hline $\begin{array}{l}\text { トューグ } \\
\text { チューフ }\end{array}$ & 0.02 & 0.09 & 40.4 & 14.8 & - & 0.15 & 1.5 & 2.3 & $\mathrm{Bal}$. \\
\hline \multicolumn{2}{l|}{ 溶接金属部 } & 0.02 & 0.01 & 50.0 & 15.1 & 2.8 & 0.26 & 1.7 & 2.7 & $\mathrm{Bal}$. \\
\hline
\end{tabular}

表 2 回転子の材料試験結果.

\begin{tabular}{|c|c|c|c|c|c|c|}
\hline $\begin{array}{l}\text { 試験 } \\
\text { 温度 }\end{array}$ & \multicolumn{2}{|c|}{$\begin{array}{l}\text { 試 験 片 } \\
\text { 採取位置 }\end{array}$} & $\begin{array}{c}0.2 \% \text { 耐力 } \\
(\mathrm{MPa})\end{array}$ & $\begin{array}{c}\text { 引張強さ } \\
(\mathrm{MPa})\end{array}$ & $\begin{array}{c}\text { 衝撃呼吸 } \\
\text { エネギー } \\
(\mathrm{J})\end{array}$ & $\begin{array}{c}\text { 電 気 } \\
\text { 抵抗率 } \\
(\mu \Omega \cdot \mathrm{cm})\end{array}$ \\
\hline \multirow{7}{*}{ 室温 } & \multicolumn{2}{|c|}{ 要求特性 } & $\geqq 800$ & $\geqq 1000$ & $\geqq 25$ & $\geqq 95$ \\
\hline & \multirow{5}{*}{$\begin{array}{l}\text { 卷 線 } \\
\text { 軸 }\end{array}$} & $\mathrm{A}$ & 954 & 1159 & 60 & \multirow{5}{*}{103} \\
\hline & & B & 918 & 1149 & 71 & \\
\hline & & $\mathrm{C}$ & 919 & 1134 & 71 & \\
\hline & & $\mathrm{D}$ & 926 & 1139 & 71 & \\
\hline & & $\mathrm{E}$ & 930 & 1128 & 76 & \\
\hline & \multicolumn{2}{|c|}{ 溶接金属部 } & 872 & 1137 & 60 & 116 \\
\hline \multirow{4}{*}{$4 \mathrm{~K}$} & \multicolumn{2}{|c|}{ 要求特性 } & $\geqq 1000$ & $\geqq 1400$ & $\geqq 25$ & $\geqq 90$ \\
\hline & \multirow{2}{*}{$\begin{array}{l}\text { 巻線 } \\
\text { 和軸 }\end{array}$} & A & 1176 & 1556 & 63 & \multirow{2}{*}{91} \\
\hline & & $\mathrm{B}$ & 1153 & 1551 & 72 & \\
\hline & \multicolumn{2}{|c|}{ 溶接金属部 } & 1100 & 1585 & 58 & 103 \\
\hline
\end{tabular}

\section{4. ま め}

以上のよらに著者らが開発した超電導発電機回転子用 $\mathrm{Ni}$ 基超合金と大型化製造技術は超速応型超電導発電機としては 世界最大の $70 \mathrm{MW}$ 容量の回転子を製造可能にした画期的な ものであり, 今後, 超電導発電機の実用化に向けて大きな前 進につながるものである.なお, 本研究は通産省工業技術院 ニューサンシャイン計画「超電導電力応用技術開発」の一環 として新ェネルギー・産業技術総合開発機構(NEDO)から の受託により，超電導発電関連機器 · 材料技術研究組合 (Super-GM)の研究テーマとして実施したものである.

\section{文献}

(1) R. G. Thompson: J. Metals, July, (1988), 44.

(2) H. L. Eiselstein: Metals Engineering Quarterly, (1971), 20.

( 3 ) O. Matsumoto, M. Kohno, T. Honjo, M. Okamura, K. Hattori, Y. Tsuda and N. Suzuki: Adv. Cryog. Eng., 40(1994), 1331.

(4) N. Suzuki, T. Murakami, K. Suzuki, S. Asai, M. Tanaka and Y. Kobayashi: Adv. Cryog. Eng., 38(1992), 61.

( 5 ) K. Miyaike, M. Inukai, T. Kitajima, T. Aiba, T. Matsuda, Y. Tsuda, N. Suzuki and Y. Kobayashi: Proceedings of ICOPE93, Vol. 1 (1993), 309. 